\title{
The Current Perspectives of Stem Cell Therapy in Orthopedic Surgery
}

\author{
Serkan Akpancar,, ${ }^{1, *}$ Oner Tatar, ${ }^{2}$ Hasan Turgut, ${ }^{3}$ Faruk Akyildiz, ${ }^{1}$ and Safak Ekinci ${ }^{4}$ \\ ${ }^{1}$ Department of Orthopedic Surgery, Gulhane Military Hospital, Ankara, Turkey \\ ${ }^{2}$ Department of Orthopedic Surgery, Air Force Academy Kasımpasa Military Hospital, Istanbul, Turkey \\ ${ }^{3}$ Department of Orthopedic Surgery, Bursa Military Hospital, Bursa, Turkey \\ ${ }^{4}$ Department of Orthopedic Surgery, Agri Military Hospital, Agri, Turkey \\ "Corresponding author: Serkan Akpancar, Department of Orthopedic Surgery, Gulhane Military Medicine Academy, Ankara, Turkey. Tel: +90-5443229700, Fax: +90-3124045500, \\ E-mail: drserkanakpancar@gmail.com
}

Received 2016 April 07; Revised 2016 June 16; Accepted 2016 June 23.

\begin{abstract}
Context: Musculoskeletal injuries may be painful, troublesome, life limiting and also one of the global health problems. There has been considerable amount of interest during the past two decades to stem cells and tissue engineering techniques in orthopedic surgery, especially to manage special and compulsive injuries within the musculoskeletal system.

Evidence Acquisition: The aim of this study was to present a literature review regarding the most recent progress in stem cell procedures and current indications in orthopedics clinical care practice. The Medline and PubMed library databases were searched for the articles related with stem cell procedures in the field of orthopedic surgery and additionally the reference list of each article was also included to provide a comprehensive evaluation.

Results: Various sources of stem cells have been studied for orthopedics clinical care practice. Stem cell therapy has successfully used for major orthopedic procedures in terms of bone-joint injuries (fractures-bone defects, nonunion, and spinal injuries), osteoarthritis-cartilage defects, ligament-tendon injuries, femoral head osteonecrosis and osteogenesis imperfecta. Stem cells have also used in bone tissue engineering in combining with the scaffolds and provided faster and better healing of tissues.

Conclusions: Large amounts of preclinical studies have been made of stem cells and there is an increasing interest to perform these studies within the human population but preclinical studies are insufficient; therefore, much more and efficient studies should be conducted to evaluate the efficacy and safety of stem cells.
\end{abstract}

Keywords: Stem Cells, Orthopedic Surgery, Mesenchymal Stem Cells, Adipose Derived Stem Cells, Bone Marrow Derived Stem Cells

\section{Context}

Musculoskeletal injuries may be painful, troublesome, life limiting and also one of the global health problems. Various treatment modalities are available for treating these problems; however, the most effective method is controversial (1-3). Current research has focused on identifying novel and effective methods of addressing the morbidity associated with musculoskeletal injuries. Stem cells are a promising and growing area of researches within the medical field (4).

Stem cells are described as to have a potential to differentiate more than 200 different cell types in the body. They are specific cell types that can create new cells in existing healthy tissues and may help to repair tissues in those structures that are injured or damaged when they differentiate into multi lineages and becoming multipotent under appropriate conditions (5). They primarily create progenitor cells and these cells have capability of more specialized functions, such as brain cells, red blood cells, bone or cartilage (2). Among the different sources for cell therapy, mesenchymal stem cells (MSCs) are the most preferred source because they can differentiate to many different tissues, in terms of muscles, bones, fat and cartilage (6), and can be obtained from many sources, such as bone, tendon, skin, adipose tissue, umbilical cord, blood and amnion (7-11).

Over the past 15 years, orthopedic surgeons have focused their attention to MSCs therapies $(12,13)$. There are plenty of animal studies that have successful results and there is an increasing concern about their use in human studies6. In these studies, stem cell procedures have been focused on promoting fracture healing and nonunion, regenerating articular cartilage in degenerated joints, healing ligaments or tendon injuries, and replacing degenerative vertebral disks (6).

\section{Evidence Acquisition}

The aim of this study was to present a literature review regarding the most recent progress in stem cell procedures and current indications in orthopedics clinical care practice. The inclusion criteria for this review were all the study types related with orthopedics surgery and stem cell therapy. Studies evaluating different methods, and stem cell procedures nonrelated with orthopedic surgery were excluded. The Medline and PubMed library databases (1946 
to the 15th of December 2015) were searched for the articles related with stem cell procedures in the field of orthopedic surgery and additionally the reference list of each article was also included to provide a comprehensive evaluation.

\section{Results}

\subsection{Types of Stem Cells}

3.1.1. Embryonic Stem Cells

James Thompson firstly described embryonic stem cells in 1988 (14). These cells can be obtained from blastocysts during in-vitro fertilization especially on the fifth days of fetal life, and they are characterized as pluripotent cells. They can be proliferated easily in the cell culture, and differentiate into every different cell type, and thus controlling stem cell growth and differentiation is difficult. Embryonic stem cells are usually preferred for transplantation, but the rejection risk is higher. Only a limited number of animal studies have been conducted on embryonic stem cells.

\subsubsection{Mature Stem Cells}

Mature stem cells were described in the 1960's. They can be obtained from body tissues, the umbilical cord or placenta after birth and they are characterized as multipotent cells. In this type of stem cells, differentiating is limited and these cells are similar to the cells from which they originate. They are not perceived as foreign by the immune system. Tissue and organ regeneration and repair are enhanced by these cells.

Stem cells are also classified into 4 types according to differentiating potential; totipotent cells are only be present in early embryo, pluripotent cells can differentiate to every cells, multipotent cells can differentiate to limited number of cells and unipotent cells are the mature form (15) (Figure 1).

\subsection{Stem Cell Procedures in Orthopedic Surgery}

Stem cell therapy has recently become popular in orthopedics surgery, especially in the musculoskeletal injuries. Musculoskeletal injuries can involve tendons and ligaments, bone, the meniscus and cartilage. When not treated properly, patients can have long-lasting symptoms such as large bone defects, pseudoarthrosis and nonunions $(16,17)$.

Therapeutic applications can be performed using stem cells as progenitor cells, and they are primarily aspired from bone marrow then injected directly into tissues to enhance the repair process. Mesenchymal stem cells that are obtained from bone marrow have chondrogenic, osteogenic and radiogenic potentials (18). After differentiation to mesenchymal progenitor cells, these cells support to bone formation by osteogenesis; adipose tissue by adipogenesis; cartilage formation by chondrogenesis; muscle formation by myogenesis; tendon/ligament formation by tendo/ligamentogenesis; and neuron-like cell formation by neurogenesis.

Many sources of stem cells have been studied for orthopedic procedures; however, the optimal source of stem cells has not yet been clearly defined (Figure 2).

\subsubsection{Sources of Stem Cells Used for Orthopedic Procedures}

3.2.1.1. Bone Marrow Derived Mesenchymal Stem Cells (BMMSCs)

Bone is the most common used stem cell source that can differentiate into musculoskeletal system cells (trabecular bone, tendon, articular cartilage, ligaments) in the suitable environment as an origin of multipotent cells (19, 20). However, bone marrow aspiration can be painful, and various complications have been stated by many authors (21).

\subsubsection{Adipose Derived Stem Cells (AD-MSCs)}

Adipose tissue has recently described as a reliable source for MSCs $(22,23)$. The procedure is less invasively as a lipo-aspiration $(24,25)$. Recent studies have shown that ADMSCs have a considerable potential for proliferation, and maximal strength to serum deprivation-induced apoptosis $(26,27)$.

\subsubsection{Synovial Tissue-Derived Stem Cells (ST-MSC)}

Synovial tissue is another source of stem cells used for orthopedic procedures (28). There are few studies available in the literature about synovial tissue-derived stem cells. Many of them have reported better outcomes in the functional scores, pain and patient satisfaction in especially cartilage repair procedures (29).

\subsubsection{Peripheral Blood-Derived Progenitor Cells}

MSCs can be also prepared from peripheral blood. Automated cell separator (apheresis) used in this procedure for collecting progenitor cells. The first two clinical studies were published in 2011 by Saw et al. (30). Both of the studies demonstrated successful results in the treatment of regenerated cartilage. In the histological evaluation, proteoglycan and type II collagen proportion was substantially increased and achieved 95\% of the normal articular cartilage score (31).

\subsubsection{Bone Marrow Concentrate}

This procedure was proposed by Buda et al. (32) and Gobbi et al. (33) and the iliac crest is used for this technique. Bone marrow is aspirated and then centrifuged. 


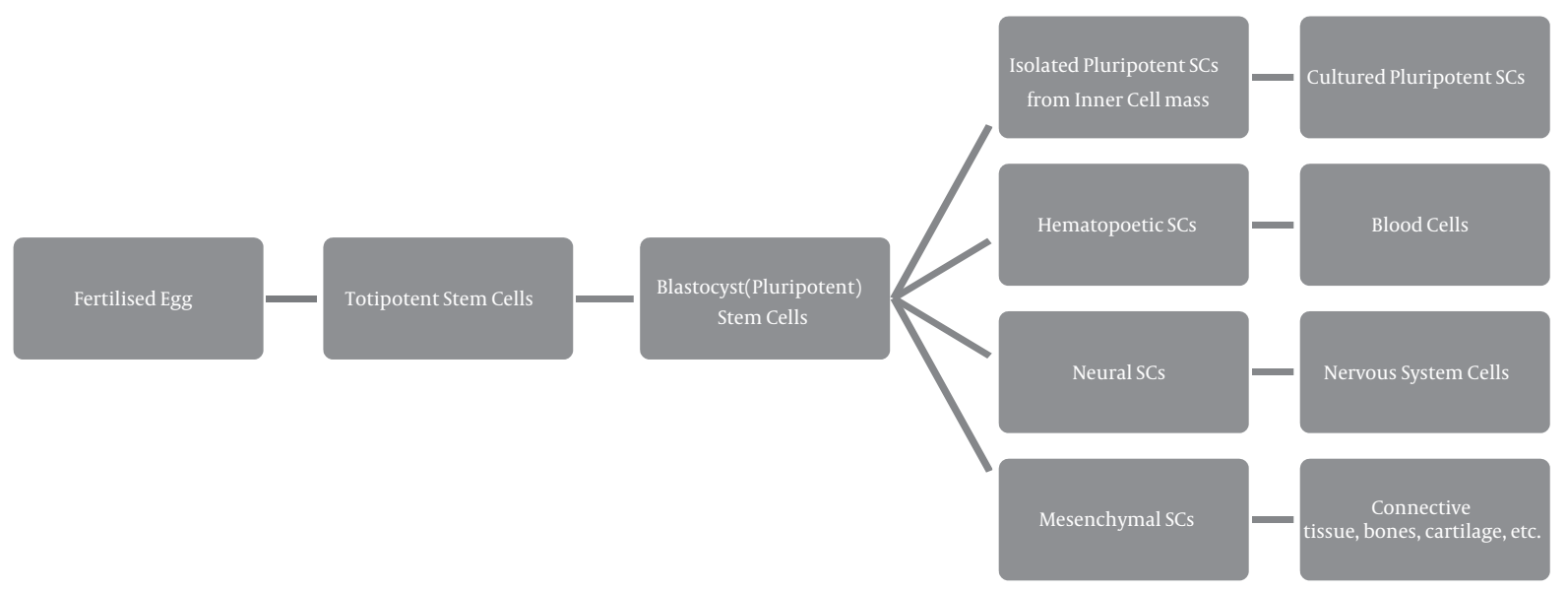

Figure 1. Types of Stem Cells According to Differentiating Potential

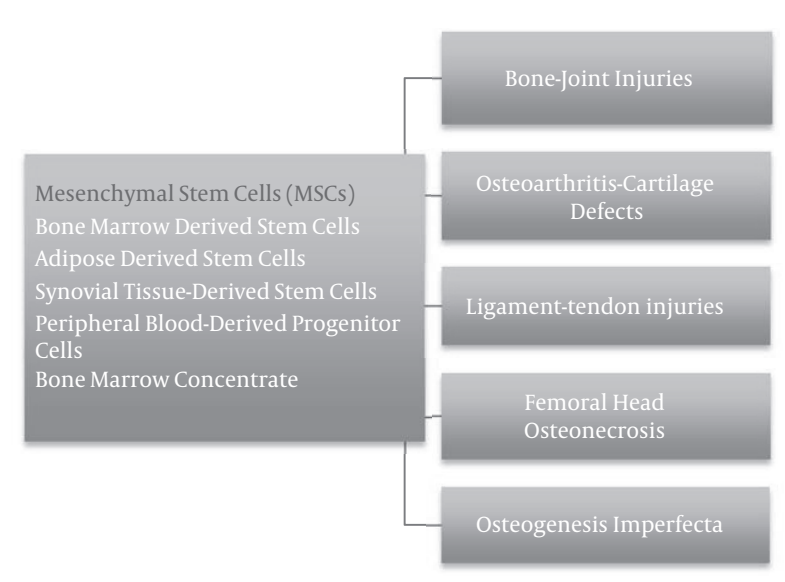

Figure 2. Mesenchymal Stem Cell Sources and the Most Preferred Conditions in Orthopedic Surgery

Both of the studies reported satisfactory clinical results, especially in cartilage regeneration.

AD-MSCs and BM-MSCs have been most preferred sources of MSCs; however, there is a controversy about the most effective source of MSCs for orthopedic procedures (34). Joseph et al. (35) comprised human cortical bone fraction (CBF-MSCs), BM-MSCs and AD-MSCs, and declared that CBF-MSCs's osteogenic potential was superior to BMMSCs and AD-MSCs in normoxia and hypoxia. Veriter et al. (36) used AD-MCSs in 11 patients with bone nonunion and 7 patients of nonhealing chronic wounds and obtained successful results in both of the situations and did not face with serious side effects or adverse events.

\subsection{Stem Cells in Bone Tissue Engineering Studies}

In light of the previous studies, stem cells have been used in bone tissue engineering. Bone tissue engineering promises alternative tools that develop a microenvironment that holds osteogenic, osteoinductive and osteoconductive properties. In the recent studies, researchers have developed strategies of combined use of MSCs and three-dimensional biodegradable polymeric scaf-folds. In addition, Udehiya et al. (37) declared that combined use of hydroxyapatite scaffolds and BM-MSCs provides faster and better healing of bone segmental defects in a rabbit model, when compared to hydroxyapatite alone. Muwan Chen et al. (38) declared that in vitro bone marrow human mesenchymal stem cells that combined with hyaluronic acid and b-Tri calcium phosphate-coated polymeric scaffold provided enhanced osteogenic differentiation and cellular proliferation and reorganization of the cellular matrix.

Colosimo et al. (39) isolated BM-MCSs from 8 New Zealand white adult rabbits than combined scaffold-BMMSCs and compared to cells cultured in absence of scaffolds. They obtained promising results for bone marrow regeneration in vitro and in vivo settings. There are a few studies available in the literature in this area; therefore, further studies are needed to investigate the most efficient cell-scaffold combination approach.

\subsection{Orthopedic Indications of Stem Cells (Table 1)}

\subsubsection{Bone-Joint Injuries}

Bone fractures and trauma-related joint injuries are the primary issue of orthopedic surgery and account for a large number of surgical procedures. The management and treatment methods have developed in consistent with 
the increasing number of scientific researches and technological possibilities, thus patient satisfaction, and quality of regenerated tissue have increased, and recovery time and treatment related complications have decreased. Nonetheless, complications such as non-union, delayed union, pseudoarthrosis, infections, loss of range of motion, and articular damage and bone defects have been continued; therefore, there is a need for new techniques that fasten fracture healing especially in the patients with comorbidities or complicated fractures. Recently stem cell procedures have investigated in the field of orthopedics to deal such these problems and successful results were obtained.

\subsubsection{Fractures-Bone Defects}

After high-energy trauma or gunshot injuries, bone defects may occur from extrusion of bony fragments. Bone defects are one of the major challenging situations of orthopedic surgery. In this area, the first stem cell study was performed by Masquelet $(40,41)$ and then by Henrich et al. (42), they used membranes that contain MSCs for the femoral defects, and declared vascular endothelial growth factor, BMP-2, TGF $\beta$ and were significantly elevated in the membranes. This raises the question of whether BMDSCs can be used to repair bone defects. Lio et al. (43) investigated the results of preclinical studies that used BMDSCs (bone marrow derived stem cells) for fracture healing in their systematic review, and stated that BMDSCs enhance bone formation and increase bone mineral density.

\subsubsection{Nonunion}

In ABD 6.2 million fractures occurred per year and 5\% - $10 \%$ of them resulted as nonunion. This is one of the devastating problems and accounts for higher rates of patient morbidity and mortality $(44,45)$. There is an increasing concern about stem cell studies in this area and successful results have been reported. Bajada et al (46). used BM-MCSs and a calcium sulphate to a patient with tibial nonunion. His fracture was refectory to other treatments and he underwent 6 previous unsuccessful operations. They declared complete union in a short time period with BM-MCSs and a calcium sulphate (46). Giannotti et al. (47) used BMDSCs for nonunion of long bones of 7 patients and obtained successful results. Grgurevic et al. (48) stated that combined BMDSCs and BMP1-3 increase type-I collagen and osteocalcin in the nonunion of rat long bones.

\subsubsection{Spinal Injuries}

Traumatic spinal cord injury is one of the most common reasons of severe neurological damage and recovery rates are very low (49). Recently, stem cells have been conducted for axonal regeneration. Sykova et al. (49) performed BMDSCs for 20 patients whom had spinal cord injury and declared beneficial outcomes with this method. Ya-jing Zhou et al. (50) used bone marrow mesenchymal stem cell transplantation in combination with propofol for spinal cord injury of rats and stated that the effectiveness of bone marrow mesenchymal stem cell transplantation increased with propofol in the treatment of spinal cord injury in rats.

\subsubsection{Osteoarthritis-Cartilage Defects}

Osteoarthritis is the debilitating, degenerative joint disorder. The disease commonly affects the weight bearing joints, formed $40 \%-60 \%$ of the musculoskeletal disorders (51-53). In the early stages of the disease, the joint cartilage is degenerated and joint space become narrow thus affects the patient comfort and physical activity. Recently, stem cell studies have obtained promising results in this area and provided remarkable regeneration of joint cartilage and became a considerable alternative of the nonsurgical options $(54,55)$.

\subsubsection{Cartilage Defects}

Regeneration capacity of damaged hyaline cartilage is very limited; therefore, some materials are needed for efficient and faster repair. Mesenchymal cells are the novel methods and many authors have recommended them because they have a reliable and reproducible effect on cartilage repair recently. Human bone marrow stem cells (hMSCs) have shown to have chondrogenic and regenerative potential in the considerable number of studies (5456). Mesenchymal stem cells have a potential to produce a cartilage-like tissue with a matrix based on type II collagen and aggrecan under suitable culture conditions $(57,58)$. In the clinical practice, isolated chondrocytes have been prepared from healthy cartilage tissue and cultured with the cell culture and then, they intra-articularly injected to knees.

Wakitani firstly reported clinical application of MSCs in the treatment of osteoarthritic knees and declared better arthroscopic and histological outcomes (59). Murdoch et al. (60) stated that cultured human bone marrow mesenchymal stem cells with Transwell permeable membranes as specific growth and a differentiation factor, provided rigid translucent cartilaginous discs and expressed cartilage-specific structural proteins as aggrecan and type II collagen. Zhu et al. (61) preferred the combination of BM-MCSs and a connective tissue growth factor, and they stated that the regenerated hyaline cartilage was similar to normal hyaline cartilage after the treatment. Guo et al. (62) used BM-MSCs combined with TGF-beta in the treatment 
Table 1. Major Orthopedic Indications of Stem Cells

\begin{tabular}{lccc}
\hline $\begin{array}{l}\text { Major Orthopedic } \\
\text { Bone-Joint Injuries }\end{array}$ & $\begin{array}{c}\text { Problems } \\
\text { Osteoarthritis-Cartilage Defects }\end{array}$ & Ligament-Tendon Injuries & Other Conditions \\
\hline Fractures-Bone defects & Cartilage Defects & Rotator cuff lesions & Meniscopathy \\
Nonunion & Osteoarthritis & Anterior cruciate ligament lesions & Femoral Head Osteonecrosis \\
Spinal İnjuries & & Achilles Tendon Rupture & Osteogenesis Imperfecta \\
\hline
\end{tabular}

of full-thickness defects of articular cartilage and declared successful results. Reyes et al. (63) stated that BMDSCs combined with BMP had successful results in the repair of rabbit's osteochondral defects.

\subsubsection{Ligament-Tendon Injuries}

A nearly half of the musculoskeletal injuries involve soft tissue injuries such as ligaments or tendons (64). Complete ligament and tendon healing require a wider period of time up to 1 to 2.5 years postinjury and the healed tissue may have less organized collagen fibrils that resulted in decreased mechanical strength; therefore, re-injury and re-rupture risks are increased (65-68).

In general, most of the authors have stated that stem cell therapy fasten and improve ligament-tendon healing; however, some literatures have contradictory results (69-71). Saether et al. (72) stated that MSCs can provide improved healing of ligament-tendon injuries. However, lower doses of MCSs are more efficient to improve healing when compared to higher doses. In this area stem cell studies were lower and have contradictory results. So, there is a need for continued research to optimize stem cell protocols, enhance beneficial outcomes and reduce the risk of re-injury.

\subsubsection{Rotator Cuff Lesions}

Rotator cuff lesions are very common in the adults and elderly. Patients are often subjected to rotator cuff injury at a rate of $58 \%$ after shoulder trauma $(73,74)$. Tears within the rotator cuff are associated with muscle pathology, such as weakness or impingement (75). The ruptures successfully treated with open or arthroscopic techniques; however, re-rupture rates were high $(76,77)$. Yokoya et al. (78) treated infraspinatus lesions of the rats with polyglycolic acid combined with BM-MCSs or isolated polyglycolic acid. They determined successful results in the combined group when compared to the isolated group.

\subsubsection{Anterior Cruciate Ligament Lesions}

Knee injuries are very common and $17 \%-61 \%$ of them required surgical repair (79). Mesenchymal stem cells and
ACL fibroblasts are determined to have regenerative effects on anterior cruciate ligament lesions (80).

\subsubsection{Achilles Tendon Rupture}

Achilles tendon ruptures are common in adults. Adams et al. (81) compared the effectiveness of sutures with BMDSCs and without BMDSCs on histological and mechanical strength in the treatment of Achilles ruptures of rats, and stated that sutures with BMDSCs had significantly better results than sutures without BMDSCs.

\subsubsection{Medial Collateral Ligament Lesions}

Saether et al. (69) evaluated the effectiveness of MCSs in the treatment of medial collateral ligament (MCL) injury of rats and stated that primed MSCs resulted in less inflammation and provides high quality of healing in the short time period.

\subsubsection{Other Conditions}

\subsubsection{Meniscopathy}

Meniscopathies are common in every age group. In the progressive stages of meniscopathies, biomechanics of knee deteriorate, and if it is not properly treated eventually osteoarthritic changes occur in the knee joint. Hatsushika et al. (82) performed BM-MSCs to the porcine massive meniscus defect model and evaluated with MRI and stated that BM-MSCs can promote meniscus regeneration.

\subsubsection{Femoral Head Osteonecrosis}

It is one of the progressive diseases that commonly seen in the younger adults by disruption of femoral head nutrition and joint degeneration. Papakostidis et al. (83) comprised the results of core decompression and local MSC in treatment of femoral head avascular necrosis and found that MSC therapy decreases the requirement of total knee arthroplasty in the patents with femoral head AVN.

\subsubsection{Osteogenesis Imperfecta}

It is one of the genetic disorders of mesenchymal cells and characterized by generalized osteopenia, bone deformity and fractures. Complete cure is impossible with the 
current treatment methods. Horwitz et al. (84) stated that bone mineral density increased and long-term fractures were decreased in the patients with osteogenesis imperfecta with the treatment of BM-MSCs.

\section{Conclusions}

There has been considerable amount of interest during the past two decades to stem cells and tissue engineering techniques in orthopedic surgery, especially to manage special and compulsive injuries within the musculoskeletal system. Large amounts of preclinical studies have been made of stem cells and there is an increasing interest to perform these studies within the human population but preclinical studies are insufficient, thus more research should be conducted to evaluate the safety and efficacy of stem cells.

\section{Footnotes}

Authors' Contribution: All authors contributed to and approved the manuscript.

Conflict of Interests: The authors declare that there is no conflict of interests regarding the publication of this paper.

\section{References}

1. Bilgic S, Durusu M, Aliyev B, Akpancar S, Ersen O, Yasar SM, et al. Comparison of two main treatment modalities for acute ankle sprain. PakJMed Sci. 2015;31(6):1496-9. doi:10.12669/pjms.316.8210. [PubMed: 26870123].

2. Kelsey J. Epidemiology of musculoskeletal disorders. New York: Oxford University Press; 1982.

3. Lawrence RC, Hochberg MC, Kelsey JL, McDuffie FC, Medsger TJ, Felts WR, et al. Estimates of the prevalence of selected arthritic and musculoskeletal diseases in the United States.J Rheumatol. 1989;16(4):427-41. [PubMed: 2746583].

4. Tucker BA, Karamsadkar SS, Khan WS, Pastides P. The role of bone marrow derived mesenchymal stem cells in sports injuries. I Stem Cells. 2010;5(4):155-66. [PubMed: 22314864].

5. Bongso A, Lee EH. Stem cells: their definition, classification and sources. In: Bongso A, Lee EH, editors. Stem Cells: from bench to bedside.. 10. Singapore: World Scientific Publishing; 2005.

6. Desiderio V, De Francesco F, Schiraldi C, De Rosa A, La Gatta A, Paino F, et al. Human $\mathrm{Ng} 2+$ adipose stem cells loaded in vivo on a new crosslinked hyaluronic acid-Lys scaffold fabricate a skeletal muscle tissue. J Cell Physiol. 2013;228(8):1762-73. doi: 10.1002/jcp.24336. [PubMed: 23359523].

7. Riekstina U, Muceniece R, Cakstina I, Muiznieks I, Ancans J. Characterization of human skin-derived mesenchymal stem cell proliferation rate in different growth conditions. Cytotechnology. 2008;58(3):15362. doi: 10.1007/s10616-009-9183-2. [PubMed: 19219561].

8. Wang Y, Zhao L, Hantash BM. Support of human adiposederived mesenchymal stem cell multipotency by a poloxameroctapeptide hybrid hydrogel. Biomaterials. 2010;31(19):5122-30. doi: 10.1016/j.biomaterials.2010.03.007. [PubMed: 20347134]
9. Gutierrez-Aguirre $\mathrm{CH}$, Gomez-De-Leon A, Alatorre-Ricardo J, CantuRodriguez OG, Gonzalez-Llano O, Jaime-Perez JC, et al. Allogeneic peripheral blood stem cell transplantation using reduced-intensity conditioning in an outpatient setting in ABO-incompatible patients: are survival and graft-versus-host disease different?. Transfusion. 2014;54(5):1269-77. doi: 10.1111/trf.12466. [PubMed: 24898453].

10. Lovati AB, Corradetti B, Cremonesi F, Bizzaro D, Consiglio AL Tenogenic differentiation of equine mesenchymal progenitor cells under indirect co-culture. Int J Artif Organs. 2012;35(11):996-1005. doi: 10.5301/ijao.5000129. [PubMed: 23065882].

11. Corradetti B, Meucci A, Bizzaro D, Cremonesi F, Lange Consiglio A. Mesenchymal stem cells from amnion and amniotic fluid in the bovine. Reproduction. 2013;145(4):391-400. doi: 10.1530/REP-12-0437. [PubMed: 23404849].

12. Diederichs S, Shine KM, Tuan RS. The promise and challenges of stem cell-based therapies for skeletal diseases: stem cell applications in skeletal medicine: potential, cell sources and characteristics, and challenges of clinical translation. Bioessays. 2013;35(3):220-30. doi 10.1002/bies.201200068. [PubMed: 22948900].

13. Rothrauff BB, Tuan RS. Cellular therapy in bone-tendon interface regeneration. Organogenesis. 2014;10(1):13-28. doi: 10.4161/org.27404. [PubMed: 24326955]

14. Thomson JA, Itskovitz-Eldor J, Shapiro SS, Waknitz MA, Swiergiel JJ, Marshall VS, et al. Embryonic stem cell lines derived from human blastocysts. Science. 1998;282(5391):1145-7. [PubMed: 9804556].

15. Hans RS. The potential of stem cells: An inventory. Human biotechnology as Social Challenge, England, Ashgate Publishing, Ltd. 2007:28.

16. Marmotti A, de Girolamo L, Bonasia DE, Bruzzone M, Mattia S, Rossi $\mathrm{R}$, et al. Bone marrow derived stem cells in joint and bone diseases: a concise review. Int Orthop. 2014;38(9):1787-801. doi: 10.1007/s00264014-2445-4. [PubMed: 25005462].

17. Pastides PS, Welck MJ, Khan WS. Use of bone marrow derived stem cells in trauma and orthopaedics: A review of current concepts. World J Orthop. 2015;6(6):462-8. doi: 10.5312/wjo.v6.i6.462. [PubMed: 26191493].

18. Caplan AI, Bruder SP. Mesenchymal stem cells: building blocks for molecular medicine in the 21st century.Trends Mol Med. 2001;7(6):25964. [PubMed: 11378515].

19. Caplan AI. The mesengenic process. Clin Plast Surg. 1994;21(3):429-35 [PubMed: 7924141].

20. Zhu H, Guo ZK, Jiang XX, Li H, Wang XY, Yao HY, et al. A protocol for isolation and culture of mesenchymal stem cells from mouse compact bone. Nat Protoc. 2010;5(3):550-60. doi: 10.1038/nprot.2009.238. [PubMed: 20203670]

21. Hjortholm N, Jaddini E, Halaburda K, Snarski E. Strategies of pain reduction during the bone marrow biopsy. Ann Hematol. 2013;92(2):1459. doi: 10.1007/s00277-012-1641-9. [PubMed: 23224244].

22. Zuk PA, Zhu M, Ashjian P, De Ugarte DA, Huang JI, Mizuno H, et al Human adipose tissue is a source of multipotent stem cells. Mol Biol Cell. 2002;13(12):4279-95. doi:10.1091/mbc.E02-02-0105. [PubMed 12475952].

23. De Ugarte DA, Morizono K, Elbarbary A, Alfonso Z, Zuk PA, Zhu M, et al. Comparison of multi-lineage cells from human adipose tissue and bone marrow. Cells Tissues Organs. 2003;174(3):101-9. [PubMed: 12835573].

24. Amos PJ, Kapur SK, Stapor PC, Shang H, Bekiranov S, Khurgel M, et al. Human adipose-derived stromal cells accelerate diabetic wound healing: impact of cell formulation and delivery. Tissue Eng Part A. 2010;16(5):1595-606. doi: 10.1089/ten.TEA.2009.0616. [PubMed: 20038211].

25. Schaffler A, Buchler C. Concise review: adipose tissue-derived stromal cells-basic and clinical implications for novel cell-based therapies. Stem Cells. 2007;25(4):818-27. doi: 10.1634/stemcells.2006-0589. [PubMed: 17420225]. 
26. Park JY, Jeon HJ, Kim TY, Lee KY, Park K, Lee ES, et al. Comparative analysis of mesenchymal stem cell surface marker expression for human dental mesenchymal stem cells. Regen Med. 2013;8(4):453-66. doi: 10.2217/rme.13.23. [PubMed: 23826699].

27. Valenzuela CD, Allori AC, Reformat DD, Sailon AM, Allen RJ, Davidson $\mathrm{EH}$, et al. Characterization of adipose-derived mesenchymal stem cell combinations for vascularized bone engineering. Tissue Eng Part A. 2013;19(11-12):1373-85. doi: 10.1089/ten.TEA.2012.0323. [PubMed: 23343199].

28. De Bari C, Dell'Accio F, Tylzanowski P, Luyten FP. Multipotent mesenchymal stem cells from adult human synovial membrane. Arthritis Rheum. 2001;44(8):1928-42. doi: 10.1002/15290131(200108)44:8<1928::AID-ART331>3.0.CO;2-P. [PubMed: 11508446].

29. Sekiya I, Muneta T, Horie M, Koga H. Arthroscopic Transplantation of Synovial Stem Cells Improves Clinical Outcomes in Knees With Cartilage Defects. Clin Orthop Relat Res. 2015;473(7):2316-26. doi: 10.1007/s11999-015-4324-8. [PubMed: 25925939].

30. Saw KY, Anz A, Merican S, Tay YG, Ragavanaidu K, Jee CS, et al. Articular cartilage regeneration with autologous peripheral blood progenitor cells and hyaluronic acid after arthroscopic subchondral drilling: a report of 5 cases with histology. Arthroscopy. 2011;27(4):493-506. doi: 10.1016/j.arthro.2010.11.054. [PubMed: 21334844].

31. Saw KY, Anz A, Jee CS, Ng RC, Mohtarrudin N, Ragavanaidu K. High Tibial Osteotomy in Combination With Chondrogenesis After Stem Cell Therapy: A Histologic Report of 8 Cases. Arthroscopy. 2015;31(10):190920. doi: 10.1016/j.arthro.2015.03.038. [PubMed: 26008951].

32. Buda R, Vannini F, Cavallo M, Grigolo B, Cenacchi A, Giannini S. Osteochondral lesions of the knee: a new one-step repair technique with bone-marrow-derived cells. J Bone Joint Surg Am. 2010;92 Suppl 2:2-11. doi: 10.2106/JBJS.J.00813. [PubMed: 21123588].

33. Gobbi A, Karnatzikos G, Sankineani SR. One-step surgery with multipotent stem cells for the treatment of large full-thickness chondral defects of the knee. Am J Sports Med. 2014;42(3):648-57. doi: 10.1177/0363546513518007. [PubMed: 24458240].

34. Strioga M, Viswanathan S, Darinskas A, Slaby O, Michalek J. Same or not the same? Comparison of adipose tissue-derived versus bone marrow-derived mesenchymal stem and stromal cells. Stem Cells Dev. 2012;21(14):2724-52. doi:10.1089/scd.2011.0722. [PubMed: 22468918].

35. Fernandez-Moure JS, Corradetti B, Chan P, Van Eps JL, Janecek T, Rameshwar P, et al. Enhanced osteogenic potential of mesenchymal stem cells from cortical bone: a comparative analysis. Stem Cell Res Ther. 2015;6:203. doi: 10.1186/s13287-015-0193-z. [PubMed: 26503337].

36. Veriter S, Andre W, Aouassar N, Poirel HA, Lafosse A, Docquier PL, et al. Human Adipose-Derived Mesenchymal Stem Cells in Cell Therapy: Safety and Feasibility in Different "Hospital Exemption" Clinical Applications. PLoS One. 2015;10(10):0139566. doi: 10.1371/journal.pone.0139566. [PubMed: 26485394].

37. Udehiya RK, Aithal HP, Kinjavdekar P, Pawde AM, Singh R, et al. Comparison of autogenic and allogenic bone marrow derived mesenchymal stem cells for repair of segmental bone defects in rabbits. Res Vet Sci. 2013;94(3):743-52. doi: 10.1016/j.rvsc.2013.01.011. [PubMed: 23414969].

38. Chen M, Le DQ, Kjems J, Bunger C, Lysdahl H. Improvement of Distribution and Osteogenic Differentiation of Human Mesenchymal Stem Cells by Hyaluronic Acid and beta-Tricalcium Phosphate-Coated Polymeric Scaffold In Vitro. Biores Open Access. 2015;4(1):363-73. doi: 10.1089/biores.2015.0021. [PubMed: 26487981].

39. Colosimo A, Rofani C, Ciraci E, Salerno A, Oliviero M, Maio ED, et al. Osteogenic differentiation of CD271(+) cells from rabbit bone marrow cultured on three phase PCL/TZ-HA bioactive scaffolds: comparative study with mesenchymal stem cells (MSCs). Int J Clin Exp Med. 2015;8(8):13154-62. [PubMed: 26550238].

40. Masquelet AC, Begue T. The concept of induced membrane for reconstruction of long bone defects. Orthop Clin North Am. 2010;41(1):27-37. doi:10.1016/j.ocl.2009.07.011. [PubMed: 19931050] table of contents.

41. Masquelet AC, Fitoussi F, Begue T, Muller GP. [Reconstruction of the long bones by the induced membrane and spongy autograft]. Ann Chir Plast Esthet. 2000;45(3):346-53. [PubMed:10929461].

42. Henrich D, Seebach C, Nau C, Basan S, Relja B, Wilhelm K, et al. Establishment and characterization of the Masquelet induced membrane technique in a rat femur critical-sized defect model.JTissue Eng Regen Med. 2013 doi: 10.1002/term.1826. [PubMed: 24668794].

43. Liao Y, Zhang XL, Li L, Shen FM, Zhong MK. Stem cell therapy for bone repair: a systematic review and meta-analysis of preclinical studies with large animal models. Br J Clin Pharmacol. 2014;78(4):718-26. doi: 10.1111/bcp.12382. [PubMed: 24645974].

44. Bostrom MP, Saleh KJ, Einhorn TA. Osteoinductive growth factors in preclinical fracture and long bone defects models. Orthop Clin North Am. 1999;30(4):647-58. [PubMed: 10471769].

45. Hak DJ. Management of aseptic tibial nonunion. J Am Acad Orthop Surg. 2011;19(9):563-73. [PubMed: 21885702].

46. Bajada S, Harrison PE, Ashton BA, Cassar-Pullicino VN, Ashammakhi $\mathrm{N}$, Richardson JB. Successful treatment of refractory tibial nonunion using calcium sulphate and bone marrow stromal cell implantation. J Bone Joint Surg Br. 2007;89(10):1382-6. doi: 10.1302/0301620X.89B10.19103. [PubMed: 17957083].

47. Giannotti S, Trombi L, Bottai V, Ghilardi M, D’Alessandro D, Danti S, et al. Use of autologous human mesenchymal stromal cell/fibrin clot constructs in upper limb non-unions: long-term assessment. PloS one. 2013;8(8):73893.

48. Grgurevic L, Macek B, Mercep M, Jelic M, Smoljanovic T, Erjavec I, et al. Bone morphogenetic protein (BMP)1-3 enhances bone repair. Biochem Biophys Res Commun. 2011;408(1):25-31. doi: 10.1016/j.bbrc.2011.03.109. [PubMed: 21453682].

49. Sykova E, Homola A, Mazanec R, Lachmann H, Konradova SL, Kobylka $\mathrm{P}$, et al. Autologous bone marrow transplantation in patients with subacute and chronic spinal cord injury. Cell Transplant. 2006;15(89):675-87. [PubMed: 17269439].

50. Zhou YJ, Liu JM, Wei SM, Zhang YH, Qu ZH, Chen SB. Propofol promotes spinal cord injury repair by bone marrow mesenchymal stem cell transplantation. Neural Regen Res. 2015;10(8):1305-11. doi: 10.4103/1673-5374.162765. [PubMed: 26487860].

51. Spector TD, Hart DJ. How serious is knee osteoarthritis?. Ann Rheum Dis. 1992;51(10):1105-6. [PubMed:1444621].

52. Felson DT, Lawrence RC, Dieppe PA, Hirsch R, Helmick CG, Jordan JM, et al. Osteoarthritis: new insights. Part 1: the disease and its risk factors. Ann Intern Med. 2000;133(8):635-46. [PubMed: 11033593].

53. Hootman JM, Helmick CG. Projections of US prevalence of arthritis and associated activity limitations. Arthritis Rheum. 2006;54(1):226-9. doi: 10.1002/art.21562. [PubMed: 16385518].

54. Cheng A, Hardingham TE, Kimber SJ. Generating cartilage repair from pluripotent stem cells. Tissue Eng Part B Rev. 2014;20(4):257-66. doi: 10.1089/ten.TEB.2012.0757. [PubMed: 23957872].

55. Khan WS, Hardingham TE. Cartilage tissue engineering approaches applicable in orthopaedic surgery: the past, the present, and the future. J Stem Cells. 2012;7(2):97-104. [PubMed: 23550348].

56. Decker RS, Koyama E, Pacifici M. Genesis and morphogenesis of limb synovial joints and articular cartilage. Matrix Biol. 2014;39:5-10. doi: 10.1016/j.matbio.2014.08.006. [PubMed: 25172830].

57. Johnstone B, Hering TM, Caplan AI, Goldberg VM, Yoo JU. In vitro chondrogenesis of bone marrow-derived mesenchymal progenitor cells. Exp Cell Res. 1998;238(1):265-72. doi: 10.1006/excr.1997.3858. [PubMed: 9457080].

58. Murdoch AD, Grady LM, Ablett MP, Katopodi T, Meadows RS, Hardingham TE. Chondrogenic differentiation of human bone marrow stem cells in transwell cultures: generation of scaffold-free cartilage. Stem Cells. 2007;25(11):2786-96. doi:10.1634/stemcells.2007-0374. [PubMed: 17656642].

59. Wakitani S, Imoto K, Yamamoto T, Saito M, Murata N, Yoneda M. Human autologous culture expanded bone marrow mesenchymal cell transplantation for repair of cartilage defects in 
osteoarthritic knees. Osteoarthritis Cartilage. 2002;10(3):199-206. doi: 10.1053/joca.2001.0504. [PubMed: 11869080].

60. Murdoch AD, Hardingham TE, Eyre DR, Fernandes RJ. The development of a mature collagen network in cartilage from human bone marrow stem cells in Transwell culture. Matrix Biol. 2016;50:16-26. doi: 10.1016/j.matbio.2015.10.003. [PubMed: 26523516].

61. Zhu S, Zhang B, Man C, Ma Y, Liu X, Hu J. Combined effects of connective tissue growth factor-modified bone marrow-derived mesenchymal stem cells and $\mathrm{NaOH}$-treated PLGA scaffolds on the repair of articular cartilage defect in rabbits. Cell Transplant. 2014;23(6):715-27. doi: 10.3727/096368913X669770. [PubMed: 24763260].

62. Guo X, Zheng Q, Yang S, Shao Z, Yuan Q, Pan Z, et al. Repair of full-thickness articular cartilage defects by cultured mesenchymal stem cells transfected with the transforming growth factor beta1 gene. Biomed Mater. 2006;1(4):206-15. doi: 10.1088/1748-6041/1/4/006. [PubMed: 18458408].

63. Reyes R, Pec MK, Sanchez E, del Rosario C, Delgado A, Evora C. Comparative, osteochondral defect repair: stem cells versus chondrocytes versus bone morphogenetic protein-2, solely or in combination. Eur Cell Mater. 2013;25:351-65. [PubMed: 23832688] discussion 365.

64. James R, Kumbar SG, Laurencin CT, Balian G, Chhabra AB. Tendon tissue engineering: adipose-derived stem cell and GDF-5 mediated regeneration using electrospun matrix systems. Biomed Mater. 2011;6(2):025011. doi: 10.1088/1748-6041/6/2/025011. [PubMed: 21436509].

65. Frank C, Schachar N, Dittrich D. Natural history of healing in the repaired medial collateral ligament. J Orthop Res. 1983;1(2):179-88. doi: 10.1002/jor.1100010209. [PubMed: 6679860].

66. Frank C, McDonald D, Shrive N. Collagen fibril diameters in the rabbit medial collateral ligament scar: a longer term assessment. Connect Tissue Res. 1997;36(3):261-9. [PubMed: 9512894].

67. Frank C, McDonald D, Bray D, Bray R, Rangayyan R, Chimich D, et al. Collagen fibril diameters in the healing adult rabbit medial collateral ligament. Connect Tissue Res. 1992;27(4):251-63. [PubMed: 1576825].

68. Nakamura N, Hart DA, Boorman RS, Kaneda Y, Shrive NG, Marchuk LL, et al. Decorin antisense gene therapy improves functional healing of early rabbit ligament scar with enhanced collagen fibrillogenesis in vivo. J Orthop Res. 2000;18(4):517-23. doi:10.1002/jor.1100180402. [PubMed: 11052486].

69. Saether EE, Chamberlain CS, Leiferman EM, Kondratko-Mittnacht JR, Li WJ, Brickson SL, et al. Primed Mesenchymal Stem Cells Alter and Improve Rat Medial Collateral Ligament Healing. Stem Cell Reviews and Reports. Stem Cell Rev. 2015;10(1):1-12. doi: 10.1007/s12015-013-9479-7. [PubMed: 24174129].

70. Mastri M, Shah Z, McLaughlin T, Greene CI, Baum L, Suzuki G, et al. Activation of Toll-like receptor 3 amplifies mesenchymal stem cell trophic factors and enhances therapeutic potency. Am J Physiol Cell Physiol. 2012;303(10):C1021-33. doi: 10.1152/ajpcell.00191.2012. [PubMed: 22843797].

71. Liotta F, Angeli R, Cosmi L, Fili L, Manuelli C, Frosali F, et al. Toll-like receptors 3 and 4 are expressed by human bone marrow-derived mesenchymal stem cells and can inhibit their T-cell modulatory activity by impairing Notch signaling. Stem Cells. 2008;26(1):279-89. doi: 10.1634/stemcells.2007-0454. [PubMed: 17962701].

72. Saether EE, Chamberlain CS, Leiferman EM, Kondratko-Mittnacht JR, Li WJ, Brickson SL, et al. Enhanced medial collateral ligament heal- ing using mesenchymal stem cells: dosage effects on cellular response and cytokine profile. Stem Cell Rev. 2014;10(1):86-96. doi 10.1007/s12015-013-9479-7. [PubMed: 24174129].

73. Sorensen AK, Bak K, Krarup AL, Thune $\mathrm{CH}$, Nygaard M, Jorgensen $\mathrm{U}$, et al. Acute rotator cuff tear: do we miss the early diagnosis? A prospective study showing a high incidence of rotator cuff tears after shoulder trauma. J Shoulder Elbow Surg. 2007;16(2):174-80. doi: 10.1016/j.jse.2006.06.010. [PubMed: 17169582].

74. Gomoll AH, Katz JN, Warner JJ, Millett PJ. Rotator cuff disorders: recognition and management among patients with shoulder pain. Arthritis Rheum. 2004;50(12):3751-61. doi:10.1002/art.20668. [PubMed: 15593187].

75. Lundgreen K, Lian OB, Engebretsen L, Scott A. Lower muscle regenerative potential in full-thickness supraspinatus tears compared to partial-thickness tears. Acta Orthop. 2013;84(6):565-70. doi: 10.3109/17453674.2013.858289. [PubMed: 24171689].

76. Bollier M, Shea K. Systematic review: what surgical technique provides the best outcome for symptomatic partial articular-sided rotator cuff tears?. Iowa Orthop J. 2012;32:164-72. [PubMed: 23576937].

77. Funakoshi T, Majima T, Iwasaki N, Suenaga N, Sawaguchi N, Shimode $\mathrm{K}$, et al. Application of tissue engineering techniques for rotator cuff regeneration using a chitosan-based hyaluronan hybrid fiber scaffold. Am J Sports Med. 2005;33(8):1193-201. doi: 10.1177/0363546504272689. [PubMed: 16000663].

78. Yokoya S, Mochizuki Y, Natsu K, Omae H, Nagata Y, Ochi M. Rotator cuff regeneration using a bioabsorbable material with bone marrowderived mesenchymal stem cells in a rabbit model. Am J Sports Med. 2012;40(6):1259-68. doi: 10.1177/0363546512442343. [PubMed 22491821].

79. Louw QA, Manilall J, Grimmer KA. Epidemiology of knee injuries among adolescents: a systematic review. BrJ Sports Med. 2008;42(1):210. doi: 10.1136/bjsm.2007.035360. [PubMed: 17550921].

80. Chen J, Altman GH, Karageorgiou V, Horan R, Collette A, Volloch $\mathrm{V}$, et al. Human bone marrow stromal cell and ligament fibroblast responses on RGD-modified silk fibers. J Biomed Mater Res A. 2003;67(2):559-70. doi: 10.1002/jbm.a.10120. [PubMed: 14566798].

81. Adams SJ, Thorpe MA, Parks BG, Aghazarian G, Allen E, Schon LC. Stem cell-bearing suture improves Achilles tendon healing in a rat model. Foot Ankle Int. 2014;35(3):293-9. doi: 10.1177/1071100713519078. [PubMed: 24403347].

82. Hatsushika D, Muneta T, Nakamura T, Horie M, Koga H, Nakagawa Y, et al. Repetitive allogeneic intraarticular injections of synovial mesenchymal stem cells promote meniscus regeneration in a porcine massive meniscus defect model. Osteoarthritis Cartilage. 2014;22(7):941-50. doi: 10.1016/j.joca.2014.04.028. [PubMed: 24795274].

83. Papakostidis C, Tosounidis TH, Jones E, Giannoudis PV. The role of "cell therapy" in osteonecrosis of the femoral head. A systematic review of the literature and meta-analysis of 7 studies. Acta Orthop. 2016;87(1):72-8. doi: 10.3109/17453674.2015.1077418. [PubMed: 26220203].

84. Horwitz EM, Prockop DJ, Fitzpatrick LA, Koo WW, Gordon PL, Neel $\mathrm{M}$, et al. Transplantability and therapeutic effects of bone marrowderived mesenchymal cells in children with osteogenesis imperfecta. Nat Med. 1999;5(3):309-13. doi: 10.1038/6529. [PubMed: 10086387] 